\title{
HOE HET EILAND SINT MAARTEN WERD VERDEELD \\ DOOR
}

\section{FRED. OUDSCHANS DENTZ.}

In het weekblad La Guadeloupe Nouvelle van 6 Juli 1929, 1ste jrg. no. 15 lazen wij de volgende mededeeling. „Nous avons retrouvé une vieille légende relative au partage de l'ile deSaint-Martin entre les Français et les Hollandais. Nous la publions a titre documentaire sans, évidement, pouvoir en garantir l'authenticité".

De kolonie was juist door de Spanjaarden verlaten, die het onder leiding van den grooten avonturier en beroemden zeevaarder Christophorus Colombus, hadden ontdekt, alsmede tegelijkertijd de kleine groep eilandjes, welke men noemt de archipel van de kleine Antillen of eilanden boven den wind, waarvan het deel uitmaakt. Het had voor hen geen belang naar rijke en vruchtbare eilanden, naar schatten te zoeken; zij hadden niets gevonden, zelfs geen water.

Na dit verlaten gebeurde het, dat er tegelijkertijd twee booten aankwamen (zoo zegt de legende), een aan het Oosten, een Hollandsche en een aan het Westen, een Fransche. Weldra werden van beide booten sloepen neergelaten om de elite van de nieuwe avonturiers aan wal te brengen, die minder ambitieus waren en ook minder op den uitkijk naar goud (steeds volgens de legende). Een ding is zeker, dat, aangezien ze nergens eenig teeken van bewoning hadden gezien, ze in den waan bleven, en niet zonder reden, dat ze meesters en eigenaars van het eiland waren en dit denkbeeld lachte hun zoodanig toe, dat zij zich vol hoop naar het binnenland verspreidden.

Het gebeurde, zonder twijfel door Gods voorzienigheid, dat de twee groepen elkaar ontmoetten op den top van een schilderachtige heuvel, niet ver van de plaats van ontscheping. Nadat het eerste oogenblik van verrassing voorbij was, welke twee menschen, die elkaar niet verwachtten te ontmoeten, vanzelf hebben, hadden zij elk het goede denkbeeld om te begrijpen, dat de eigendomsrechten van ieder hunner gelijk waren en zonder veel omslag 


\section{HOE HET EILAND SINT MAARTEN WERD VERDEELD}

haalde de een uit zijn voedseltasch jenever en bier en de andere eenige flesschen Bordeau Chambertin Champagne (op dit punt is de kroniek niet erg juist) maar het is in ieder geval duidelijk, dat ieder zijn geliefde nationale drank te voorschijn bracht.

Er is niets, zooals men weet, dat de menschen tot een vlugger accoord en vergelijk brengt dan het klinken der glazen en het ledigen van eenige flesschen wijn, bier en jenever.

Aldus bezegeld, werd de vriendschap en eensgezindheid weldra volkomen tusschen Hollander en Franschman en er was slechts één raad en één stem, dat men namelijk een overeenkomst moest maken. Van dien dag af heet de berg waarop deze merkwaardige ontmoeting heeft plaats gehad: Mont des Accords, welke naam hij tot heden draagt.

Er werd overeengekomen, dat het gedeelte van het land dat aan ieder zou worden toegekend zou afhangen van een wedstrijd in het loopen. Van elke groep zou een flinke man den volgenden morgen op hetzelfde uur van een zeker punt in tegengestelde richting vertrekken, zoodat die elkaar na ongeveer een dagmarsch zouden ontmoeten: verder, dat van het punt waar ze elkaar zouden ontmoeten, een denkbeeldige lijn zou worden getrokken, welke beide partijen als grens zouden aannemen.

Er gebeurde toen wat gebeuren moest, dat is, dat de Fransche kampioen, een Béarnais en Bask, sterk gespierd en waarschijnlijk nog onder den invloed van den goeden wijn van Jurançon, die de kinderen van zijn land met de melk hunner moeders drinken, en waarvan onze goede koning Henri IV kan getuigen, veel vlugger liep dan de prachtige Hollander, die daarentegen ietwat bezwaard was door het bier en de goede melk van zijn land.

Ziedaar hoe het gebeurde (zegt steeds de kroniek), dat Frankrijk vandaag twee derde van het eiland bezit, hetgeen het aan de voortreffelijke druiven van Jurançon te danken heeft.

Dezelfde legende - korter verteld - wordt medegedeeld door Algernon E. Aspinall in "The Pocket Guide to the West Indies”, London, Chicago, New York 1914, blz. 276. Ze is overgenomen in "De W.I. Gids" van Augustus 1920, 2e jg., blz. 223.

Red. W.-I. G. 